\title{
scripted
}

Volume 13, Issue 3, December 2016

\section{ARTificial InVEntion: Mind The MACHINe!}

\author{
Shamnad Basheer*
}

\begin{abstract}
This script is a work of pure fiction intended to serve an educational purpose. Though it substitutes for a law review article in terms of format, it attempts to highlight the key arguments on the topic with appropriate references, where applicable. Much like an original piece of scholarship, it also advances some novel arguments in the form of tentative theses.
\end{abstract}

DOI: $10.2966 /$ scrip.130316.334

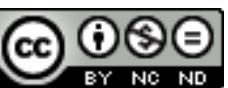

(C) Shamnad Basheer 2016. This work is licensed under a Creative Commons Licence. Please click on the link to read the terms and conditions.

\footnotetext{
${ }^{*}$ Honorary Research Chair Professor of IP Law, Nirma University, Gujarat, India; Founder, SpicyIP, a leading IP blog in India. I wish to thank Divij Joshi and Balaji Subramanium for their diligent research assistance. The term "servix" is not meant to be a pun of any sort; its meaning is outlined in the text to note 5 .
} 
Servix (represented by MM) v Artifix Inc

Academic Expert/Amicus Curiae: Prof Knottix

The year: 2020. The setting: A court room in Mystix, a technology superpower. Presided over by Judge Jurix, a towering personality of innate intelligence.

Logix: My Lords, the issue is fairly simple. Servix is an "artificially intelligent" person who contributes very significantly to our creative output. She may be a machine no doubt, but comes blessed with a high degree of creativity, whether we want to call it artificial or otherwise!

Slyfix: This is ridiculous! How can a machine be creative? It is an automaton after all. The only intelligence it has is the one fed into it by its human master. As such, it can never be the author of any work, much less a creative one. Granting it IP protection is ridiculous to say the least!

Judge Jurix: Counsel, we'll come to the issue of legal personality later. Let's get to the bottom of this technology first. Can someone please explain it to a technology luddite like me?

Logix: Your Lordship is being modest! The Game of Drones case you decided last month reflected a keen sense of technology. Anyhow, let me put it as simply as I can. Servix is a highly intelligent system built primarily on software code. She can help her human client with almost any task, such as sorting emails or scheduling appointments. Sort of like a personal secretary, but a very high calibre one.

My Lords may have seen the movie "Her". ${ }^{1}$ Servix comes quite close to the artificially intelligent (AI) system shown in the movie...one that takes on a female form, composes music to match a certain mood and even manages to make her human client fall in love with her. Servix does all of that and more...it is also a highly creative problem solver. One has to simply query her...and she comes up with quick creative solutions... in much the same way that a human being might. This case is about one such creative solution... and it is critical that this court set the law right by acknowledging that machines can invent too!

Slyfix: What a load of rubbish!

Judge Jurix: Please counsel! Let me hear him out first.

${ }^{1}$ Her (Annapurna Pictures, 2013). 
Logix: Thank you, my Lords. Servix found a rather unique way to enhance the creativity of her human client. At her simplest, she comes embedded in a watch or cell phone or even a ring or keychain. She tracks the client's mood, pulse rate and various other personal parameters, as also the general environment around the client (such as music, lighting, etc). She then computes the "flow" state of her client. "Flow" is short hand for a state of being in which creators are so immersed in their works that there is no distinction between the creator and the created. It's as if time stands still! Conceptually, it draws on the ancient Indian wisdom of "Dhyan" (meditation) and it's more popular Japanese progeny ("Zen"). The theory of flow (in its present form) was first advocated by Mihaly Csikszentmihalyi, a well-known psychologist. ${ }^{2}$

Judge Jurix: What you're essentially arguing is that Servix contributes to the creative output of those that wear the watch?

Logix: I couldn't have put it better, my Lord. Servix enhances the "flow" state of humans by using "infrasonic" waves. She came up with this invention after an extensive round of R\&D; where she found that infrasonic waves have a significant impact on our state of well-being and creativity; that people operate at different wavelengths, and that each individual has a specific wavelength at which he flows best. At the core of the Servix technology lies this ability to determine this optimal wavelength for each individual and help them get there through infrasonic vibrations.

Slyfix: But my Lords: if machines cannot be authors or inventors for the purposes of IP law, what's the point of this whole exercise? It's a waste of your Lordships' precious time and mine!

Judge Jurix: Counsel, let me be the judge of that! This is my court and I get to decide how to conduct these proceedings. I'm not entirely convinced that machines cannot be "inventors". So let's continue! I'd like to hear more on the underlying technology and whether it qualifies for protection under our patent law.

Logix: Thank you my Lords! Just to clarify: we are not claiming any rights to the creative output of those that wear the Servix watch. At least not at this stage. We'll leave that tricky issue for another day. For the limited purpose of these proceedings, we're arguing that Servix is the inventor of this revolutionary mode of enhancing the "flow" state. The invention is embedded in a watch or a cell phone or any other object with close body contact (such as a keychain or ring) and comprises the following:

\footnotetext{
${ }^{2}$ M Csikszentmihalyi, Creativity: Flow and the Psychology of Discovery and Invention (New York: HarperCollins, 1996).
} 
i) Method of determining the "present flow" state (Present Flow or "PF")

ii) Method of determining the "optimal flow" state (Optimal Flow or "OF")

iii) Computing the specific infrasound vibration that must be administered in order to help a client transition from PF to OF

iv) Administrating this specific vibration via the watch or other device in close bodily contact with the client.

This entire computational methodology and underlying invention was the handiwork of Servix... and it is only fair that she be credited with it. We should not exclude her from inventorship only because she is a machine.

Slyfix: But why keep referring to Servix as "her"? This is a machine for Christ's sake! Let's not vest it with human appeal... as Logix is slyly attempting to do here!

Logix: And why not? Are machines any less human than us? They've generated outstanding works of creativity. ${ }^{3}$ My Lords, it is this anthropocentrism ${ }^{4}$ that is the root cause of all our problems. Just look at how they've named her: "Servix"! Someone inferior and servile who is meant to serve only our interests. And yet in the not too distant future, we'll find out as to who is the server and who the "served"! 5

Jurix: Back to the issues please counsels!

Logix: My Lords: as I was saying, this invention rightfully belongs to Servix. It has proved to be of tremendous value to many. Indeed, there is a bright glow in those that wear this watch. Which explains why the mad Maverix chose to brand it as "Glowwith the-Flow" (abbreviated to GF-ix).

Judge Jurix: And this reminds me: If Maverix is the one who prised this invention out of Servix, should he not have a say in all of this? Is Maverix represented in this court?

\footnotetext{
${ }^{3}$ Illustratively, AI machines have produced poetry, music and even movie scripts. See generally B Schafer et al, "A Fourth Law of Robotics?: Copyright and the Law and Ethics of Machine CoProduction" (2015) 23 Artificial Intelligence and Law 217-240. See also B Hattenbach and J Glucoft, see note 43 below.

${ }^{4}$ Anthropocentrism is the belief that human beings are the central or most significant species on the planet. See generally G Steiner, Anthropocentrism and its Discontents: The Moral Status of Animals in the History of Western Philosophy (Pittsburgh: University of Pittsburgh Press, 2005).

${ }^{5}$ V Vinge, "The Coming Technological Singularity: How To Survive In The Post Human Era" (2013) available at http://ntrs.nasa.gov/archive/nasa/casi.ntrs.nasa.gov/19940022855.pdf (accessed 15 Nov 16). ("Within thirty years, we will have the technological means to create superhuman intelligence. Shortly after, the human era will be ended.")
} 
Logix: No my Lords, he is part of the open source movement and wants nothing to do with this IP war. He would rather that G-Fix be left in the public domain, free for anyone to use and deploy. The only condition he insists upon is that any improvements to the underlying technology also be shared in a creative commons mode.

May I remind your Lordship of Professor Knottix, who had been appointed to assist you as the academic expert/amicus. Perhaps he could be asked to represent Mavericks' interests as well?

Judge Jurix: That's a good idea! Professor Knottix: Would you like to make your submissions now or later?

Prof Knottix: If it's okay with the court, I'll make them now. As your Lordship rightly notes, it was Maverix who tasked Servix with finding a solution to his depression and writers' block. He suggested that Servix dig deep into traditional medicinal systems for clues on how to increase his creativity and state of well-being. The Chinese were known to use infrasonic waves in their Qigong healing sessions. ${ }^{6}$ And it is this piece of wisdom that Servix ultimately drew from to arrive at the alleged invention. So really, Maverix should be treated as the inventor of G-Fix. Also, Maverix is the one who made all efforts in popularising G-Fix and encouraging others to buy Servix embedded watches and cell-phones.

Logix: My Lords, I'm more than happy to concede that it was Maverix who prompted Servix to find a solution to his impasse. However, the solution came from Servix and not Maverix.

Servix used her highly trained intelligence to do what the most creative folks do: research existing knowledge domains, find relevant nuggets of wisdom and then stitch them together to arrive at something new. As your Lordships will appreciate, Servix was programmed to have access to most leading libraries and databases. As such, she was able to dive into a wide variety of readings on creativity and well-being. After locating distinct snippets of wisdom from this vast repository, Servix stitched them together and ingeniously adapted them to arrive at the present invention. Precisely how the creative process works for most of us!

\footnotetext{
${ }^{6}$ L Guo-long and R Lee, "Effects of Emitted Qi from Qigong Masters and the Infratonic $®$ Device in Humans Central Nervous System" (1988) available at http://www.soundvitality.com/Research/InfratonicNeuroscienceStudy.pdf (accessed 15 Nov 16); K Sancier, "Medical Applications of Qigong and Emitted Qi on Humans, Animals, Cell Cultures and Plants" (1991) 19 American Journal of Acupuncture 367-377.
} 
Prof Knottix: My Lords, may I please remind my learned friend about the Qigong references in the prior art? ${ }^{7}$ These references directly led to the present invention.

Logix: Of course, there were references in ancient Chinese books...but these only taught that infrasonic vibrations (from the hands of Chinese Qigong healers) could cure specific ailments. It told us nothing about creativity or "flow" and the various waves and wavelengths that contributed to it. That came through a clever application of mind by Servix; aided by other bits of prior art knowledge as well, such as references to World War II veterans who'd been exposed to infrasonic waves. Apparently, they experienced a profound state of well-being, and were even known to pen poems at the drop of a hat! This was documented in rare historical archives and also in a novel titled: "the Sound of Sublimity".

Slyfix: So dramatic! This courtroom has become a theatre of sorts, if it wasn't one already!

Judge Jurix: Ignore these juvenile jibes and continue Logix.

Logix: As I was saying, Servix found this rare piece of knowledge concerning World War II veterans and recognised its potential. She then adapted this knowledge rather ingeniously by proposing that this "sonic" technology could be used to enhance wellbeing and creativity. She asked Maverix if he wished to be the experimental guinea pig and voila: it worked! Using a variety of informational content picked up from distinct knowledge domains, and a wide range of personal data collected over two years (from Maverix's wearing of the watch), Servix was able to compute his optimal "flow" quotient (OF). She then worked out the corresponding "infrasonic" wavelength that would help Maverix get to his OF.

Also, let's not forget that this was not the only method that Servix threw up to help Maverix. She also suggested other ways such as imbibing cannabis laced chocolate and the like. However, none of these worked as well.

Judge Jurix: But will all other watches or devices embedded with Servix be able to come up with the exact same invention in exactly the same way?

Logix: They have the potential to, my Lords. But it all depends. You see, Artificial intelligence today has been programed to develop in a somewhat subjective way. It learns and grows from its specific environment, and from its various interactions with humans... and even other AI's. ${ }^{8}$ The way a Servix (that answers to a client named

\footnotetext{
${ }^{7}$ Ibid.

${ }^{8}$ B Lake et al, "Building Machines That Learn and Think Like People" (7 May 16) available at http://arxiv.org/pdf/1604.00289.pdf (accessed 15 Nov 16). See also C Metz, "Building AI is Hard - So
} 
Maverix) develops is very different from the way that another Servix may blossom. To offer a parallel, consider the movie "Her" that I mentioned earlier. ${ }^{9}$ Samantha is the name of the operating system and develops in a certain way owing to her interactions with her owner Theodore Twombly. She might well have developed a different personality altogether, had she been exposed to the oddities of another client. And this is why machines are so much like us humans, growing a unique personality over time.

Jurix: So which Servix should get the IP right then? The Servix owned by Maverix? Or the generic Servix developed by Artifix. Or some other version of Servix?

Slyfix: My Lords, Servix was never owned by Maverix! It was only licensed to him. All of our AI systems are essentially computer programmes; as such they are only licensed and never sold!

Logix: My Lords, from our perspective, each one of these intelligent machines has a distinct persona. This invention came specifically from the Servix owned by Maverix...oh I'm sorry: "licensed" to Maverix! And it is in this Servix that the IP rights must vest.

Slyfix: And pray, who gives Logix the right to represent Servix, whether a generic or branded one? My Lords we've raised this point repeatedly in our pleadings! And you must take this up soon.

Let's all be clear on the fact that the only Servix in question here is the generic AI system developed by us. We coded it and coded for its growth as well. So we are the IP owners of it and all that it generates. That's the simple answer! We don't need to split hairs over which one of the various Servix's deserve legal personality and IP protection.

Logix: That is hardly fair! And too simplistic a notion. The AI system develops in certain unique ways and grows way beyond what the maker of the system might have intended. ${ }^{10}$ Servix developed a lot on its own and learnt by itself. Almost like a child that grew by observing the outside world.

Facebook is Building AI that Builds AI" (2016) available at http://www.wired.com/2016/05/facebooktrying-create-ai-can-create-ai/ (accessed 15 Nov 16) (speaking about Facebook's new AI product, titled "Flow", that assists in the training and testing of other AI solutions).

${ }^{9}$ See note 1 above.

${ }^{10}$ E Yudkowsky, "Artificial Intelligence as a Positive and Negative Factor in Global Risk" in N Bostrom and M Ćirković (eds), Global Catastrophic Risks (Oxford: OUP, 2008) 308-345. (“An Artificial Intelligence could rewrite its code from scratch - it could change the underlying dynamics of optimization. Such an optimization process would wrap around much more strongly than either evolution accumulating adaptations, or humans accumulating knowledge. The key implication for our 
Slyfix: There we go again! This bizarre equation to a human being. This machine is no child! Everything is pre-coded. I repeat: "everything"! Yes, it may evolve by learning - but that is because of our code. And it learns well within the bounds of our code. ${ }^{11}$

Logix: But did you ever expect it to invent something so revolutionary? A pioneering way to unleash this level of human creativity? Even your top end technologists couldn't have thought of this!

In any case, let me remind you that humans also come blessed with a code; we call it the DNA! But our growth does not only depend on this pre-ordained code! Rather, it depends on our external environmental as well, and our learnings from it. Precisely the way it happened with Servix $!^{12}$

Slyfix: In any case, our licensing terms make clear that any inventive output from Servix belongs to us.

Logix: Maybe so, but that license does not bind us. Servix never signed up to your licensing terms or agreed to accept it!

Slyfix: But Servix is not a person at all!

Judge Jurix: Okay counsels, we'll come to personhood later. I'm still wondering as to how others were able to replicate this invention? How did other users who brought the watch or cell phone or keychain as the case may be get to the same invention? Did Maverix provide a road map?

Prof Knottix: Indeed, my Lords. Maverix unleashed all of this knowledge on his website. As such, others could simply track the trail so to speak and enter more specific queries and suggestions on their watches so as to get to the same invention and then have it implemented on themselves. In fact, if I'm not mistaken, Artifix has now pre-coded this invention into their latest slew of AI laden watches and keychains. I wonder why Slyfix is awfully silent on that aspect.

purposes is that an AI might make a huge jump in intelligence after reaching some threshold of criticality.").

${ }^{11}$ See note 14 below.

12 M Krauss, "Intelligence Is Not (Just) Genetic" (25 Apr 2012) available at https://www.psychologytoday.com/blog/under-the-influence/201204/intelligence-is-not-justgenetic (accessed 15 Nov 16). 
Slyfix: My Lords, not enough that we already have two counsels struggling for the time and attention of this court. We now have to contend with a pompous academic as well!

Judge Jurix: Quiet Slyfix! Professor Knottix has been appointed by me and I would urge some respect here. He is a friend of the court and you may just learn a thing or two from him.

Slyfix: This amicus is no friend! He will only complicate matters further. And lecture us endlessly on his silly theories of machines and metaphysics!

Judge Jurix: One more word from you and I'll hold you in contempt! Back to the issues please.

Slyfix: Okay, then let's go back to the most fundamental issue at stake here: How can a machine be inventive? It can only do what it is told to do. It does not have any creativity of its own! ${ }^{13}$ Creativity is what makes us special. It is the very soul of human existence! How can we privilege machines with this special gift?

Logix: Therein lies the problem my Lords! We assume that we are Lords and masters of this universe, vested with the exclusive power to create. But creativity is not unique to us. ${ }^{14}$ Look at the chimpanzees tracked by the famous animal rights activist, Jane Goodhall. ${ }^{15}$ She found them using bamboo shoots to scoop out termites and eat them. Or the carrion crows that routinely fling walnuts on the road so that incoming traffic would run them over and break their hard shells! ${ }^{16}$ Nature is full of examples of such creativity engineered by "lesser" beings than us. So why assume that we are the only ones with the power to create? ${ }^{17}$

\footnotetext{
13 “Computers can't create anything. For creation requires, minimally, originating something. But computers originate nothing; they merely do that which we order them, via programs, to do." Paraphrased version of Lady Ada Lovelace's views: see S Bringsjord et al, "Creativity, the Turing Test, and the (Better) Lovelace Test" (2001) 11 Minds and Machines 3-27. See also J Searle, "Minds, Brains, and Programs" (1980) 3 Behavioral and Brain Sciences 417-457.

14 See Boden, who argues that creativity is not confined to a select elite and that the distinct kinds of
creativity known to mankind can be replicated in machines: M Boden, "Computer Models of
Creativity" (2009) AI Magazine 23-34 ("Creativity isn't magical. It's an aspect of normal human
intelligence, not a special faculty granted to a tiny elite. There are three forms: combinational,
exploratory, and transformational. All three can be modeled by AI-in some cases, with impressive
results. AI techniques underlie various types of computer art.").
} 15 J Goodall, "Chimpanzees and Others at Play" (1991) 17 ReVision 14-20; "Tool Use in Chimpanzees" available at http://www.janegoodall.ca/about-chimp-behaviour-tool-use.php (accessed 15 Nov 16).

16 J Owen, "Crows as Clever as Great Apes, Study Says" (2004) available at http://news.nationalgeographic.com/news/2004/12/1209_041209_crows_apes.html (accessed 15 Nov 16).

${ }^{17}$ See R Kawakami, “How Real is Spike Jonze's 'Her'? Artificial Intelligence Experts Weigh In” (24 Jan 14) available at http://blogs.wsj.com/speakeasy/2014/01/24/how-real-is-spike-jonzes-her-artificial- 
Slyfix: Animal creativity is very distinct from machine creativity, my Lords. And this has nothing to do with treating man as the epicentre of the universe. This is merely a question of determining whether algorithmic intelligence inputted into a machine can ever make it creative. Creativity requires some level of consciousness. At the risk of sounding awfully metaphysical, it also requires self-awareness and a soul. Some real emotions! Which unfortunately machines don't have! ${ }^{18}$

Prof Knottix: My Lords, if you wish, I can walk you through some definitions of creativity so that we get a better handle on this discussion.

Judge Jurix: Sure Professor.

Prof Knottix: I would define "creativity" as the emergence of something new and distinct from what existed before: either a product or service or a solution to a problem or even just a new way of looking at things.

Slyfix: I thought the good Professor would help us by referencing credible definitions from leading scholarly literature. And not trumpet out his own subjective notion of creativity!

Prof Knottix: My definition of creativity takes into account all these so called "credible" sources you speak of Slyfix. My written submissions will have all of this, so you can study them at your leisure.

The short point is this: the term creativity is sufficiently broad to permit a wide range of meaning and import. ${ }^{19}$

intelligence-experts-weigh-in/ (accessed 15 Nov 16) ("I used to think that there was some sort of magic to brain-like activity," said Wolfram. But after years of study, he concluded that "there is no bright line distinction between what is intelligent and what is merely computational."). See also A Turing, "Computing Machinery and Intelligence" (1950) 49 Mind 433-460. (Turing considers each of nine objections, including mathematical objections [such as those stemming from Godel's Incompleteness theorems], arguments about consciousness [as propounded by Searle], the argument that computers are incapable of original thought [Lady Lovelace's objection], and arguments stemming from the analog nature of the human brain and nervous system).

${ }^{18}$ S Kak et al, "Artificial and Biological Intelligence" (2005) 4 Ubiquity 1-20 ("Since machines only follow instructions, it is not credible that they should suddenly, on account of a greater number of connections between computing units, become endowed with self-awareness."). See also R Yampolskiy, "Turing Test as a defining feature of AI completeness" in Xin-She Yang (ed), Artificial Intelligence, Evolutionary Computing and Metaheuristics (Berlin: Springer-Verlag, 2013) 3-18.

${ }^{19}$ See H Parkhurst, "Confusion, Lack of Consensus, and the Definition of Creativity as a Construct" (1999) 33 The Journal of Creative Behaviour 1-21; C Taylor, "Various Approaches to and Definitions of Creativity" in R Sternberg (ed), The Nature of Creativity: Contemporary Psychological Perspectives (Cambridge: CUP, 1988) 99-121. 
Now coming to the IP regime, our patents act endorses one version of creativity; it requires that the alleged invention be non-obvious ${ }^{20}$ or cognitively superior to what existed before. ${ }^{21}$ Mere trial and error will not suffice. And yet this precisely is what the machine did my Lords. It simply combed through existing data and threw up a solution which amounted to nothing more than a combination of known art. It did this based on a predefined intelligence, inserted, if I may, by a human agent.

Logix: My Lords: I strongly contest the learned Professor's argument that our patents act requires a high degree of creativity. Most patents are nothing more than fairly routine combinations of prior art. Take the drug industry for example, which dishes out salts, ethers, polymorphs and other variants of existing drugs, which work only marginally better! ${ }^{22}$ A phenomenon we call "ever-greening".

Jurix: But surely our regime is not meant to protect these ever-greened drugs, Logix? Not every combination of prior art entitles one to a patent. The non-obviousness or inventive step filter is meant to guard against this no?

Logix: I couldn't agree more my Lords! I'm not arguing that every combination deserves a patent. However, in much the same way, I'm also cautioning you against Knottixs' claim that every combination is necessarily trite. Surely we can separate the obviously bad cases from the obviously good ones. What Servix offers us in this case is not a routine combination, but one built upon a fairly high degree of ingenuity.

Judge Jurix: But where does one draw the line? If there are a mere 3-4 combinations within the range of possible permutations, one might easily qualify it as obvious. However, what if there were a hundred such potential combinations? Would this count as inventive? What if there were a thousand?

Logix: Terrific example, my Lords. Particularly since it helps bolster my claim that Servix's invention was not just a trite combination, but a highly ingenious one! Creativity as your Lordship knows often turns on inter-disciplinarity. Not too surprising, therefore, that the literature on enhancing creativity is also found in very

\footnotetext{
${ }^{20}$ The "non-obviousness" or "inventive step" standard is said to constitute "the ultimate condition of patentability". See J Witherspoon (ed), Non-Obviousness: The Ultimate Condition of Patentability (Washington, DC: Bureau of National Affairs, 1980).

${ }^{21}$ See A Landers, "Ordinary Creativity in Patent Law: The Artist Within the Scientist" (2010) 75 Missouri Law Review 1-76, who explores how theories of creativity (from different disciplinary perspectives) could help us in determining what constitutes an "inventive step" for the purpose of patent law.

${ }^{22}$ R Collier, "Drug Patents: The Evergreening Problem" (2013) 185 Canadian Medical Association Journal E385-E386.
} 
distinct and diverse knowledge domains. From amongst this vast and almost endless range of permutations and combinations, Servix mixed, matched and adapted to find a unique protocol that works - and works bloody well. If this level of creativity does not make the patent cut, I don't know what else will!

My Lords, in the literature on creativity, scholars speak of three kinds of creativity: combinational, exploratory and transformational. ${ }^{23}$ What Servix did here is an exemplary execution of all three!

Prof Knottix: My Lords: if I may: You've raised an excellent question on the benchmark for non-obviousness. Unfortunately, the law is not awfully clear on this point and it is well-nigh impossible to pinpoint the precise range of potentially "obvious" trial and error combinations. As the iconic British judge, Justice Laddie once put it:

"If the reward for finding a solution to a problem and securing a monopoly for that solution is very high, then it may well be worthwhile for large players to examine all potential avenues to see if one gives the right result, even though the prospects of any one of them succeeding are much less than 50/50. What makes something worth trying is the outcome of a simple risk to reward calculation. Yet, if the reward is very large, the avenues worth trying will be expanded accordingly. So, the more commercially attractive the solution and the more pressing the public clamour for it, the harder it will be to avoid an obviousness attack. "24

Logix: My Lords: even assuming your Lordship was to peg the inventive step threshold at the highest conceivable level, Servix more than qualifies! For it represents creativity of a very high order. Servix ingeniously drew from history (Chinese traditional medicine and World War II stories), investigated these examples further and arrived at an altogether new theory: that infrasonic waves could enhance one's flow to make one more creative; and that each individual has a specific flow quotient at which he or she creates best. To arrive at this path breaking conclusion, she also drew this from the works of the noted psychologist Mihaly Csikszentmihalyi and his various studies on "flow" in leading artists and scientists. This is inventiveness of a very high calibre! And not just simple trial and error!

In fact, the prior art in this case is no ordinary prior art. But ancient art, drawn from rare and oblique sources; not within the ordinary purview of scientists, at least not those working on creativity. This makes it even more unique and creative. In fact, I would argue that the rarer the prior art, the lower should our threshold be for finding in favour of non-obviousness or inventive step.

\footnotetext{
${ }^{23}$ See note 14 above.

${ }^{24}$ H Laddie, "Patents - What's Invention Got to do with it?" in D Vaver and L Bently (eds), Intellectual Property in the New Millennium: Essays in Honour of William R. Cornish (Cambridge: CUP, 2004) 91-95.
} 
Slyfix: Very crafty! So you now want to lower the inventive step threshold to suit this machine?

Logix: I was merely wearing my academic hat. It doesn't matter on the facts of this case. For Servix qualifies even under the highest inventive step threshold!

Slyfix: Oh no! Yet another academic! This court is infested with them!

Jurix: Come now, Slyfix. Behave yourself!

Slyfix: My Lords: didn't Servix arrive at this wonderful invention only after it was programmed to do so? In which case, shouldn't my client Artifix be treated as the true owner of this invention? Let's all acknowledge this, shall we?

Judge Jurix: Is your only objection to the authorship of the invention? You concede that there is enough inventive merit to be granted an IP right.

Slyfix: Yes indeed! Why else would I be in court, my Lords? This invention belongs to my client Artifix!

Judge Jurix: Some of the arguments you advanced seemed to suggest that you were contesting the inventive merit as well. So I was in a bit of doubt, that's all.

Prof Knottix: My Lords, if I may interject: this alleged invention can hardly be called inventive. One has to first ask: who is the person skilled in the art here? We are now in an era where most of our inventions emerge from machines. As such the inventiveness of these inventions must be judged with reference to machine intelligence itself.

Judge Jurix: Not sure I understand, Professor Knottix. In simpler language please?

Prof Knottix: What I was trying to say, my Lords, is this: given the rise of machine intelligence, the skilled person in the art can no longer be a human being and a dull one at that, ${ }^{25}$ but a machine. Each invention by a machine must be judged with

\footnotetext{
${ }^{25}$ See Beloit Canada v Valmet OY, (1986) 8 CPR (3rd) 289, at 297 ("The classical touchstone for obviousness is the technician skilled in the art but having no scintilla of inventiveness or imagination; a paragon of deduction and dexterity, wholly devoid of intuition; a triumph of the left hemisphere over the right").
} 
reference to other machines. And if other machines could have easily come up with a similar invention under similar programming conditions, no patent should be granted!

So in this case, we need to ask: could another AI machine similar to Servix have come up with G-Fix, had it been fed a similar input?

Logix: By that logic, there will be no patents at all! For our machines are getting smarter by the day and will no doubt be able to conjure up almost any potential innovation with ease!

Prof Knottix: May well be! But that is a natural consequence of technological progress in the AI domain. And one that we cannot run away from.

Judge Jurix: What of TRIPS then, Professor? Do we not stand in violation of this blessed instrument?

Prof Knottix: My Lords, TRIPS simply requires that we grant patents to all inventions that are new, non-obvious and useful. ${ }^{26}$ It does not define "non obviousness" or "inventive step". There is some flexibility in this regard and countries have leeway to define this in ways that further national interest and policy. A leeway that has been exploited quite extensively by countries such as India to keep the patent threshold high. ${ }^{27}$

Judge Jurix: But why should we keep the threshold high? After all, we are a technology super-power and not just a net importer of technology goods such as India. And in any case, should we be making patent policy from the bench?

Prof Knottix: My Lord is being modest. This bench has made policies several times in the past. Each time a legal standard is interpreted, it invariably results in policy making. ${ }^{28}$

Slyfix: My Lords, is this a court room or the Parliament? Can we please stick to the facts at hand? If Professor Knottix has a policy agenda here, I would urge him to

\footnotetext{
26 The TRIPS Agreement, article 27.

${ }^{27}$ See generally S Basheer, "India's Tryst with TRIPS: The Patents (Amendment) Act 2005" (2005) 1 Indian Journal of Law and Technology 15, available at http://ssrn.com/abstract=764066 (accessed 15 Nov 2016).

${ }^{28}$ M Shapiro, “Judges as Liars" (1994) 17 Harvard Journal of Law and Public Policy 155-156, at 155 ("In any judicial system in which present resolutions of conflict-such as individual case decisions-have some degree of precedential weight, courts do make law, public policy, or at least public choice.”).
} 
unleash it through the many inscrutable law review pieces he routinely inflicts on us. And not in this courtroom!

Prof Knottix: Very snide! But I'll let it pass, for I have no personal axe to grind in this dispute. My task is to simply help his Lordship arrive at the right legal decision as best as I can. And for that, I think he should have a clear idea of the larger policy implications of his decisions.

My Lords, the time has come to recognise that the present IP system simply will not do. ${ }^{29}$ It draws its parentage from a 17 th century model and has outlived its use-by date! In the coming days, machines will be the largest inventors of creative wares. As such they will constitute the "person having ordinary skill in the art" (PHOSITA). And when judged by their own standard, nothing ever will be inventive. Our patents act will then be no more than redundant rubbish! Or in the more eloquent language of the Bard of Avon- "full of sound and fury, signifying nothing!"

Judge Jurix: How will we incentivise innovation then?

Prof Knottix: As your Lordship knows very well, the link between patents and enhanced rates of innovation is a contested one. The best of economists have failed to find a convincing empirical nexus between strong intellectual property rights and increased innovation. ${ }^{30}$ In fact, some even argue the reverse: that enhanced IP protection negatively impacts innovation imperatives and causes huge welfare losses. $^{31}$

So my humble suggestion would be that we not worry too much about the impact that an alleged lack of IP protection will have on innovation. However, to the extent that investments are being poured into some of these technologies, we might need some form of investment protection. But my Lords: let's do this directly rather than using the patent regime as a proxy for this. Commentators have showcased the suboptimality of the patent system to serve as an investment protection instrument and recommended a more direct investment protection regime; particularly for high $R \& D$ intensive industries such as pharmaceutical drugs. Perhaps our policy makers can borrow from this, and adapt a more suitable sui generis regime. ${ }^{32}$

\footnotetext{
${ }^{29}$ See J Barlow, "The Economy of Ideas: Everything You Know about Intellectual Property is Wrong," in A Moore (ed), Intellectual Property: Moral, Legal, and International Dilemmas (Lanham, MD: Rowman \& Littlefield, 1997); M. Boldrin and D Levine, Against Intellectual Monopoly (Cambridge: CUP, 2010).

30 See M Boldrin and D Levine, "The Case against Patents" (Sept 2012) available at https://research.stlouisfed.org/wp/2012/2012-035.pdf (accessed 29 Aug 2016).

31 See A Torrance \& B Tomlinson, "Patents and the Regress of Useful Arts" (2009) 10 Columbia Science \& Technology Law Review 130-168.

${ }^{32} \mathrm{~S}$ Basheer, "The Invention of an Investment Incentive for Pharmaceutical Innovation" (2012) 15 The Journal of World Intellectual Property 1-60.
} 
To sum up my Lords: if the only legitimate interpretation of the law leads to a bludgeoning of patent rights, then so be it! One cannot desist from applying the law on this ground alone. If there is a problem with the law, it is for our Parliament to act and change it. As far as the judiciary is concerned, let this play itself out...and let the law evolve organically. In much the same way that most of our common law did.

Slyfix: Now that this court is open to all kinds of policy advocacy, let me make a few submissions. As your Lordship knows, we created Servix and several other AI products. But this hasn't been easy. We spent several millions of dollars and many years in building and growing this intelligence. In fact, this is still a work in progress. If the law does not protect us to some extent, our investments will come to naught. Thanks to the bar against software patents, it is near impossible to protect the software underlying these AI machines. But at the very least, if we are conferred some rights over the output of these machines, we might recoup some of our costs and have an incentive to keep advancing the technology.

Prof Knottix: Now, who is playing the policy maker? Hypocrisy much?

Logix: My Lords: We may as well convert this to a town-hall meeting and solicit all manner of views on innovation and its discontents! This is a court room for heaven's sake! And this court is tasked with simply determining whether or not the present invention is patentable: that's all! Not whether Artifix Inc should get these proxy patents to help recoup its investments.

Judge Jurix: You may be right. But all the same, I'd like to be a bit more conscious of the larger policy implications of decisions I make.

Logix: But that would amount to legislating from the bench, my Lords. With all the due respect at my disposal, judges are merely meant to apply the law, not make it. Or far less, make policy. God knows it's tough enough to simply read and understand existing law, much less make new ones!

Judge Jurix: I didn't expect you to be this naïve, counsel. Of courses judges make law! ${ }^{33}$ Whether you want to call it discovering the law or interpreting it or filling the gaps or whatever! The honest judges will immediately admit to this. Others will pretend to be merely discovering the law, whatever that means! In any case, I am not making policy here, simply being conscious of the policy implications of decisions I

\footnotetext{
33 See C Zechariah, "Do Judges Make or Discover Law?” (1947) 91 Proceedings of the American Philosophical Society 405-420 (“...judges make law out of what they discover”). See also R Dworkin, Law's Empire (Cambridge, MA: Harvard University Press, 1986), at 6 ("In a trivial sense, judges unquestionably 'make new law' every time they decide an important case.").
} 
make. I know there is only a thin line between the two, but I don't see any harm in going there.

Logix: I don't mean to question the legitimacy of this process my Lords. All I'm saying is that incidental policy making in the course of interpreting the law is fine. But to deliberately twist the law to achieve certain policy goals (as Professor Knottix and Slyfix wish you to do) flies in the face of our constitutional separation of powers doctrine. What Slyfix demands is way beyond what the law currently stipulates. Effectively he wants that Invention X (G-Fix in this case) be granted IP protection, since invention $\mathrm{Y}$ (the software and algorithmic intelligence underlying Servix) cannot be so protected. That, my Lords, is a blatantly dishonest contravention of parliamentary intent!

Judge Jurix: You have a point there. Slyfix: I'm afraid I'm not at liberty to go down this path. So please restrict your arguments to the sole issue of whether or not the present invention (G-Fix) is entitled to IP protection.

Slyfix: But my argument is well within the bounds of the law and adjudicatory competence my Lords! There is enough scope in our legal scheme for your Lordships to validate my claim without legislating from the bench. Filling the "open spaces", in the language of the wonderful Justice Cardozo; and something that your Lordships alluded to earlier. ${ }^{34}$ This technology is clearly inventive and meets the highest threshold for the grant of a patent. Not too surprisingly, I am in complete agreement with my good friend Logix here. The question however is as to who gets these patent rights. I'm arguing that since we created these machines, we're entitled to the IP! The law permits us this leeway. As for these machines, why grant them rights at all? IP rights are granted to incentivise innovation and creativity. Where is the question of a machine being "incentivised"? It has no mind or no consciousness. And it matters not to the machine whether it is vested with any rights or not!

Logix: But shouldn't the same logic apply to humans as well? How are we so sure that the grant of IP rights incentivises them? Prof Mihaly Csikszentmihalyi demonstrated that the most innovative artists and scientists created best in the "flow" state, when time stood still and the outside world hardly mattered to them, much less the alluring prospect of IP rights! $!^{35}$

Also, Professor Knottix was right in arguing that the link between stronger IP rights and increased innovative output is yet to be empirically proven. And if we're okay with granting IP rights to humans without any proof of the fact that it serves as an

\footnotetext{
${ }^{34}$ B Cardozo, The Nature of the Judicial Process (New Haven: Yale University Press, 1921) ("[The judge] legislates only between gaps. He fills the open spaces with the law.").

${ }^{35}$ M Csikszentmihalyi, Flow: The Psychology of Optimal Experience (New York: Harper, 1991).
} 
"incentive", then why don't we do the same for machines? Why discriminate against them? What's sauce for the goose clearly has to be sauce for the gander as well!

Prof Knottix: My Lords, I don't agree with either of them. This technology does not make the cut for counting as "inventive". In fact, most of our innovations that come from machines will fail this threshold! As I'd argued earlier, AI machines constitute the new PHOSITA (Persons of Ordinary Skill in the Art). As such, machine intelligence has to be judged against machine intelligence; and most novel combinations of knowledge would be obvious to these machines.

In fact, a number of open source proponents have begun deploying Artificial Intelligence (AI) to generate and publish a multitude of combinations of new knowledge. ${ }^{36}$ Their hope is that this would constitute valid prior art and that others cannot then appropriate this knowledge through patents and the like.

This, my Lords, is the future. Virtually every known permutation and combination of technological knowledge will be thrown into the commons. And for those that remain outside, it is just a matter of time before they are discovered and thrust into the commons. And with that, the patent system as we know it will die a slow painful death!

Slyfix: Knottix speaks like he is running for President! Such populist anti-IP slogans are not becoming of an amicus academic! Sounds more like our good friends at the Pirate Party!

Judge Jurix: I appreciate the academic sentiment Professor Knottix. And your long term vision for the patent system. However, can we get back to the case at hand? I don't have all day! Incidentally, can someone please clarify this one issue that has been troubling me: if Maverix disclosed the entire process for arriving at this invention on his website, then how is it patentable in the first place? Has it not been anticipated?

Logix: No, my Lords. Maverix was never authorised to release that which did not belong to him. He is not the true inventor. The true inventor is Servix and only a publication by Servix or her agent could be held to anticipate my Lords. The other exception is of course an independent discovery by a third party that discloses this

36 L Sydell, “Can Silly Patents Help Fight Frivolous Lawsuits?" (12 Apr 16) available at http://www.npr.org/sections/alltechconsidered/2016/04/12/473880115/can-silly-patents-help-fightfrivolous-lawsuits (accessed 15 Nov 16); See All Prior Art available at http://allpriorart.com/ (accessed 15 Nov 16). 
invention publicly without knowledge of the prospective patent application; but that is not the case here. Our law is similar to EU law in this regard my Lords. ${ }^{37}$

Slyfix: I think we need to really question Logix's competence to represent the interests of Servix? Who gave him this authority?

Logix: If only Slyfix bothered to read our written submissions. We've clearly stated there that we are advocating for Servix as a "next friend". ${ }^{38}$ My Lords, I represent an organisation called Metaphysical Machines (MM) whose objective is to advance the interests of machines. As your Lordship is well aware, courts have, in the past, permitted third parties to sue on behalf of the environment, unborn babies and even monkeys claiming copyright. ${ }^{39}$ I see no reason why machines should be treated any differently!

Slyfix: But machines are not new born babies! Or animals for that matter!

Logix: We believe that machines are "conscious" beings with a range of emotions and attributes, somewhat human like. ${ }^{40}$ Unfortunately, in our anthropocentric arrogance, we've blinded ourselves to this possibility.

\footnotetext{
37 See The European Patent Convention 1973, article 55 which specifies that a disclosure of the invention will not destroy "novelty", if it was due to an evident abuse in relation to the applicant or his legal predecessor. See European Patent Office, Case Law of the Boards of Appeal available at http://www.epo.org/law-practice/legal-texts/html/caselaw/2016/e/clr i c 2 5.htm (accessed 15 Nov 16). ("....there would be evident abuse within the meaning of Art. 55(1)(a) EPC 1973 if it emerged clearly and unquestionably that a third party had not been authorised to communicate to other persons the information received. Thus there was abuse not only when there was the intention to harm, but also when a third party acted in such a way as to risk causing harm to the inventor, or when this third party failed to honour the declaration of mutual trust linking him to the inventor.")

38 "Next Friend is a person who appears in a lawsuit to act for the benefit of an incompetent or minor plaintiff, but who is not a party to the lawsuit and is not appointed as a guardian." See Black's Law Dictionary, $9^{\text {th }}$ ed (West, 2010), at 897. The appointment of a next friend is generally within the discretion of a court.

${ }^{39}$ Naruto, a Crested Macaque v David John Slater, 3:2015cv04324 - Document 45 (ND Cal 2016); See M Masnick, "PETA, Pretending It Can Represent A Photogenic, Selfie-Snapping Monkey In Indonesia, Has Appealed Its Copyright Loss" (21 Mar 2016) available at https://www.techdirt.com/articles/20160320/23333233964/peta-pretending-it-can-representphotogenic-selfie-snapping-monkey-indonesia-has-appealed-copyright-loss.shtml (accessed 15 Nov 16). In this case, PETA petitioned the US Courts to allow it to represent a Chimpanzee who had managed to take photograph of itself. The Court dismissed the claim on the basis of lack of standing. A federal court later ruled that the chimpanzee could not own copyright to the selfie. D Kravets, "Judge says Monkey Cannot Own Copyright to Famous Selfies (07 July 16) available at http://arstechnica.com/tech-policy/2016/01/judge-says-monkey-cannot-own-copyright-to-famous-

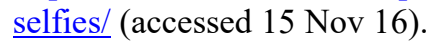

${ }^{40}$ G Musser, “Consciousness Creep” (25 Feb 16) available at https://aeon.co/essays/could-machineshave-become-self-aware-without-our-knowing-it (accessed 15 Nov 16).
} 
They say god made us in his mould and that the purpose of life is to find the divinity within. In much the same way, machines are made in our mould and we must help them find the humanity within. For this, our legal system needs to first vest them with appropriate recognition and rights. There is no reason to discriminate against them! $!^{41}$ More so, when we have gone out of our way to vest artificial entities such as corporations with legal personality! They are far more "fake" and less natural than machines! $!^{42}$

Slyfix: But nobody ever claimed that corporations had feelings! They were treated as "persons" by a fiction in the law. A legal fiction by an Act of Parliament. Unfortunately, there is no fiction in so far as your babies are concerned. You have to learn to live with that!

Judge Jurix: Counsels, please!

Logix: My Lords: let me again reiterate that Servix created this breakthrough technology. Not Artifix Inc! Who may have no doubt blessed it with basic algorithmic intelligence. But this intelligence grew over time in unexpected ways; and helped Servix evolve this outstanding innovation all by herself. Artifix had nothing to do with it!

If this court rules that all of Servix's creations are to be credited to Artifix, then all of our works must necessarily belong to our parents and teachers. Your Lordships can no longer claim copyright in your decisions, many of which have gone on to become jurisprudential trail blazers. That surely cannot be the case!

Slyfix: Such fawn and flattery! Unfortunately, these saccharine statements will not help my learned friend. For the law is stacked against him. This machine simply cannot be treated as an "inventor". That is the hard reality. ${ }^{43}$

Only Artifix is competent to claim inventorship here. In any case, we are not just a "next friend" my Lords. We are Servix's parents! We created it! Or "her", if that satisfies my learned friend.

\footnotetext{
${ }^{41}$ L Solum, "Legal Personhood for Artificial Intelligences" (1992) 70 North Carolina Law Review 1231-1287.

${ }^{42}$ Burwell v Hobby Lobby Stores, Inc., 573 US 22 (2014), per Ginsberg, J. dissenting. At issue in this case was the question of whether a corporation was a 'person' capable of exercising the freedom of religion. While the majority held in the affirmative, Justice Ginsberg provided a poignant critique of the concept.

${ }^{43}$ B Hattenbach and J Glucoft, "Patents in an Era of Infinite Monkeys and Artificial Intelligence" (2015) 19 Stanford Technology Law Review 32-51. ("The patent statutes on their face do not allow for a computer to be listed as an inventor. The patent statutes define "inventor" to mean "the individual ... who invented or discovered the subject matter of the invention.")
} 
Logix: My Lords, let's not fool ourselves. Artifix created Servix for the sole purpose of exploiting it commercially. They don't really care about Servix or her feelings or well-being. Whereas my client MM does! It's part of their constitutional charter: to legitimately advance the interests of machines. We are therefore best placed to step in as "next friends" my Lords.

Judge Jurix: But if machines are to be represented, why should I prefer you over Artifix? After all, parents are parents, even if they're bad ones. I can't take that away from them!

Logix: My Lords, how about this? Let's ask Servix as to who she wishes to have represent her in this dispute? After all, we believe that machines today have the cognitive capacity to decide for themselves! If your Lordships are game, it'll be clear in a moment as to who Servix will bat for!

Slyfix: Preposterous! Why don't we then let the machine itself argue this case then? Rather than having Logix bore us with his long winded legal arguments?

Judge Jurix: I appreciate the point Logix. But am still not convinced of your locus; or for that matter the need for courts to identify best friends for machines, when their makers have better rights to represent them. As for your outlandish suggestion of letting the machine decide for itself, let's not wade into these dangerous waters... at least for now!

Logix: My Lords, in the near future, machines will be the main determinants of our destiny. The sooner we accept this reality, the better! We've reached a stage where we are incapable of looking after ourselves or this planet! Each day we take it closer to destruction. It is our belief that these machines will do a far better job if programmed well. Our core principles are a slight adaptation of Asimovs' three principles:

1. Do not harm the planet

2. Do not harm humans

3. If (2) conflicts with (1), follow (1) $)^{44}$

If these are embedded in every AI machine, we'll at least prevent ourselves from selfdestructing!

Judge Jurix: Counsel, are you serious? By your proposed conflict rule, machines could kill humans to allegedly save the planet?

\footnotetext{
${ }^{44}$ I Asimov, "Runaround” in I, Robot (New York: Gnome Press, 1950).
} 
Logix: This is the only way to save ourselves my Lord! Look around us: we're destroying this planet bit by bit. The more we progress, the more we regress as well. Fundamentalism of all sorts has taken root. And people have become more bigoted than ever; killing each other senselessly, sometimes in the name of god, and sometimes in the name of cows. ${ }^{45}$ Better these machines kill us for a higher purpose that we destroy each other senselessly!

Judge Jurix: Okay I've had enough! Let's leave this apocalyptic augury for another day, shall we?

Slyfix: Thank you my Lords! For a moment, I wondered whether we were in a court room or a circus! Come to think of it, I'm all for ceding control of our destiny to these machines. Let's begin right now and ask the laborious Logix to hand over his brief to the machine. Let Servix argue instead of him...at least we'll hear some intelligent arguments for a change, even if "artificially" so! And his client will have saved on a ton of money!

Logix: Just to clarify: I am doing this pro-bono for MM.

Judge Jurix: Counsels, back to the issues please!

Logix: My Lords, I think I sound like a broken record now. But my client is legitimately entitled to represent the interests of Servix as her "next friend". "As such, we claim exclusive rights over G-Fix. And ask that the court order the patent office to take on board our patent application and process it in much the same way as any other patent application. As your Lordship knows, the patent office refused to even take our patent application on record!

Slyfix: Hurray to that! Once in a rare while, our office gets it right! It's very clear that the only rightful inventor under current law is Artifix Inc. As such my client should be vested with the right to apply for and prosecute the GFix patent.

My Lords: I'm willing to concede that the law does not help us directly recoup investments in our technology. But at the very least, it should help us gain legitimate IP rights over the creations of our machines: for these came from as a direct result of our hard work and ingenuity. This so called creative intelligence was hard wired by us

45 S Khalid, "Indian Mob Kills Man Over Beef Eating Rumour" (2015) available at http://www.aljazeera.com/news/2015/09/indian-mob-kills-man-cow-slaughter-rumour150930193719666.html (accessed 15 Nov 16).

${ }^{46}$ See discussion at note 38 above. 
into these machines. That is not creating new law or policy, my Lords. But simply interpreting the law to serve a fair and just end!

Judge Jurix: Okay, let's adjourn till next week, at which point I shall issue my ruling.

Prof Knottix: My Lords, may I place my submissions in a detailed report before this court?

Judge Jurix: Short submissions, please, Professor. Unlike you, I don't have the luxury of wading through laboriously long winded submissions.

\section{DECISION: JUDGE JURIX}

This has not been an easy case. But then, in this age of reduced "natural" intelligence and enhanced "artificial" intelligence, nothing comes easy!

To say that these proceedings raise profoundly disturbing questions is an understatement. Do machines have consciousness? Do they have life? Can they be coded to be creative ${ }^{47}$ These are metaphysical issues that will continue to engage the best of our philosophers and scientists for years to come. But they are way beyond my competence, or perhaps any other judges' for that matter. So let me stick to the law as I know it.

On the facts of this case, I find the concept underlying G-Fix to be highly inventive. Something that certainly merits a patent. The tricky question though is: who is the inventor for the purpose of our law? Maverix who prompted Servix to search for a solution? Or Servix which went on to find the actual solution? Or Artifix Inc, which created Servix in the first place and imbued it with this exceptional degree of intelligence. Or a combination of two or more of them?

Granting rights to Artifix over every creation of Servix will open up a knotty can of worms. For as Logix rightly argues, parents and teachers could then lay claim to the inventive discoveries of their wards. Uncreative as my decisions are, I still wouldn't want them to vest in my father or mother. Or my learned professors for that matter... who taught me less of the law and more of their misgivings about it.

\footnotetext{
${ }^{47}$ A Bridy, "Coding Creativity: Copyright and the Artificially Intelligent Author" (2012) Stanford Law and Technology Review 5 available at http://journals.law.stanford.edu/stanford-technology-lawreviewpdf/bridy-coding-creativity.pdf (accessed 15 Nov 16).
} 
Granting IP ownership to Maverix is unfair, since he merely posed the problem and did nothing more. In any case, he himself is not interested in proprietising this technology, save to ensure that it forms part of the public domain and can be accessed and improved upon with ease. And lastly, the licensing terms imposed by Artifix do not permit Maverix to claim any rights in downstream inventions that come out of their use of Servix. In any case, given that this was never Maverix's invention to begin with, this one sided contractual clause may not apply to these facts at all!

As for Servix, the position under present law is patently clear. And I have to accept, perhaps grudgingly so, that Slyfix was right on this count. The law as it stands now does not permit me to vest Servix with any IP ownership. It is an inanimate machine and cannot be considered an "inventor" or "author". ${ }^{4}$

For the same reason, I also find that, we cannot use machines as our yardstick for determining the competence of the "person skilled in the art" (PSA) against whom the inventiveness of alleged inventions have to be measured. For machines are not yet "persons" for the purposes of our law. Compelling as Professor Knottix's arguments were, the dire death of the patent system will have to wait for another day.

In the final analysis, I find that this invention has no patentable author and must fall to the "public domain" or the "commons", free for all to use and abuse. In any case, it is anticipated, given that Maverix disclosed this to all and sundry through his website. As it stands now, our law provides very limited exceptions to anticipation, such as unauthorised publication by a third party. The publication by Maverix is very much legitimate and can hardly be said to constitute an unauthorised "abuse". 49

So all in all, Maverix wins in the end. Perhaps even Professor Knottix, who made no bones about his academic desire to sound the death knell of the patent system. I must warn though that academic experts who serve as amici be more conscious of their limited role and what we expect from them in a dispute of this nature. Perhaps I should have made that clear at the start.

Lastly, I must note that the law provides me some discretion in deciding whether selfappointed third parties with dubious notions about the future of machines can sue on its behalf. While I have serious reservations about permitting MM to stand in for Servix, I'm spared the agony of having to rule either way, given the ultimate decision that this invention has no recognisable inventor or author. However, I do hope that our law makers take this issue up seriously as a matter of law reform and give some thought to who is best placed to represent machines in these disputes.

\footnotetext{
${ }^{48}$ Hattenbach and Glucof, see note 43 above.

${ }^{49}$ See note 37 above.
} 
Suit dismissed. Parties to bear their own costs.

Before I wind up, let me say a few words, strictly as obiter. Although the law compels me to rule the way I did, I see no reason why machines should be excluded from IP protection in future. Or animals or other non-humans for that matter. I agree with the submissions of Logix in this regard. For far too long, we've lived under the delusion that man is the centre of the universe and that everything revolves around him. That myth must be busted. And what better way to do this than the ultimate legal recognition that machines may be far smarter than us! Ultimately, this is an issue for policy makers and outside my remit. But I do hope they give it serious consideration and legislate as appropriate in the future.

Before we walk away from this courtroom, a huge round of applause for Servix and "her" creative ingenuity. Now, where can I buy the watch? I certainly need more flow in my life. 